Advance Journal of Food Science and Technology 16(SPL): 81-91, 2018

DOI:10.19026/ajfst.16.5941

ISSN: 2042-4868; e-ISSN: 2042-4876

(C) 2018 Maxwell Scientific Publication Corp.

Submitted: September 14, $2017 \quad$ Accepted: December 15, $2017 \quad$ Published: November 10, 2018

\title{
Research Article \\ Phenomenological based Semi-Physical Model for the Milk Evaporation Process
}

\author{
Emiro A. López-Acosta, Omar A. Pérez-Sierra, Fabián A. Ortega-Quintana, Everaldo J. Montes-Montes \\ and María N. Martínez-Miranda \\ Department of Food Engineering, Universidad de Córdoba, Montería, Colombia
}

\begin{abstract}
The aim of this study was present a Phenomenological Based Semi-physical Model (PBSM) for the milk evaporation process. The evaporation is the elimination of solvent in form of water steam from a solution. In the dairy industry, the evaporation is a pretreatment for the powder milk processes that reduce the cost of the drying process, storage and transport. Thus, an appropriated mathematical model is necessary in order to get a good control and optimized process of milk evaporation, which allows obtaining a high-quality product. Previous studies have presented mathematical models for the evaporation process. However, the majority of these models are based on maintaining constant values such as the thermal properties of fluids, latent heat of vaporization and global coefficient of heat transfer, among others and this means that there will be high errors of predictions. The aim of this model was to predict the temperature, concentration and milk level in the evaporator. The model obtained was solved using the Runge-Kutta method with the software "LABVIEW 2011" and it was quantitatively validated with experimental data from a real process using the absolute mean error. The experimental data of temperature, concentration and milk level in the evaporator were obtained applying step-like disturbances in the process variables: vacuum pressure in the evaporation chamber, steam flow and milk feeding flow. The quantitative validation showed that the obtained model can predict satisfactorily the dynamic behavior of the target variables of the milk evaporation process because the error was less than $5 \%$.
\end{abstract}

Keywords: Boiling, dairy, evaporator, heat, modeling, Runge-Kutta

\section{INTRODUCTION}

The evaporation is the elimination of the solvent how water steam from a solution. This loss of dissolvent can be done in evaporators of simple effect or multiple effects evaporators. In Colombia, this process is highly used by sugar companies, by the industry of concentrated juice and dairy industry. In the dairy industry, the evaporation is a pretreatment for the powder milk process, since this process reduces the cost of the drying process, storage and transporting (Shah and Bhagchandani, 2012; Ordoñez et al., 2012).

Thus, an appropriated mathematical model is necessary in order to get a good control and optimized process of milk evaporation, which allows obtaining a high-quality product (Russell et al., 2000). Previous studies have presented mathematical models for the evaporation process (Shah and Bhagchandani, 2012; Franco, 2007; Paramalingam, 2004). This mathematical model might differ due to empirical knowledge applied when developing the model. However, the majority of these models are based on maintaining constant values such as the thermal properties of fluids, latent heat of vaporization and overall heat transfer coefficient among others (Miranda and Simpson, 2005). This means that there will be high errors of predictions, which can cause deficiencies in the control system, discrepancies among optimal values of calculated and real process, wrong measurements of virtual sensors and other non-desired situations (Erdoğdu, 2009).

Therefore, the aim of this research was to develop a Phenomenological Based Semi-physical Model (PBSM) and validate it quantitatively for the evaporation process of milk using a simple effect evaporator, with internal heat exchanger and with vertical short tubes, in order to describe and predict the dynamics of temperatures, concentration and level of processed milk. In this model, calculation of the thermal properties in terms of temperature variations and solid concentration were considered and were used values of overall heat transfer coefficient and latent heat of vaporization with empirical models proposed in the literature.

\footnotetext{
Corresponding Author: Fabián A. Ortega-Quintana, Department of Food Engineering, Universidad de Córdoba, Montería, Colombia
} 


\section{MATERIALS AND METHODS}

This research was carried out in the Applied Engineering laboratory of the Universidad de Córdoba in the city of Montería during 2016.

A phenomenological based semi-physical model for the milk evaporation process is presented according to the methodology of Álvarez et al. (2009) as follows:

- Develop a verbal description and a process flow diagram that complement each other.

- Propose a modeling hypothesis and set a level of detail for the model according to model object or purpose.

- Define as many Process Systems (PS) in the process to be modeled as required by the level of detail set.

- Apply the principle of conservation on each defined PS. It is recommended to take at least the next balances: Total mass, $\mathrm{n}$ component mass, total energy, as thermal energy or momentum. These equations form the Dynamic Balance Equations (DBE).

- Select from DBE those equations with significant information to fulfill the model purpose as it was established in step 2. Some DBEsare redundant or are merely a numerical equality and then they must be discarded.

- Identify variables, parameters and constants of the model.

- Find constitutive equations for calculating the largest number of parameters in each PS.

- Verify the Degree of Freedom (DF) of the model (mathematical systems formed by all equations and constant values). $D F=$ Number of equationsNumber of unknown variables or parameters. DF must be zero for a solvable model.

- Build a computational model: A computer program able to solve the model without altering the true mathematical model response.
- Validate the model response using real operating conditions related to those used at step 2 to establish the objective of the model.

\section{RESULTS AND DISCUSSION}

Step 1: Develop a verbal description and a process flow diagram that complement each other.

Figure 1 shows the equipment used for the experiment, together with auxiliary equipment for variable measurement.

The evaporation process is described as follows (Fig. 2): The milk is stored in a tank of stainless steel and it is provided to the evaporator of simple effect for a membrane pump with variable control of the series DOSIVAC DD 600. The milk goes through a heat exchanger tube with configuration 1-2 in counter-flow, a step in the shell (steam) and two steps in the tubes (food), doing the preheating when interchanging thermal energy with live steam and increasing temperature until the corresponding pressure of the steam space in the equipment. Simultaneously, a saturated live steam flow at pressures between 40 and $80 \mathrm{psig}$ is strangulated by a valve through an isenthalpic process to take its pressure to a value between 10 and 15 psig. Then, this steam goes out of the tubes of the calandria and gives its latent heat to the milk column inside of the evaporator. The vapor that condensed goes

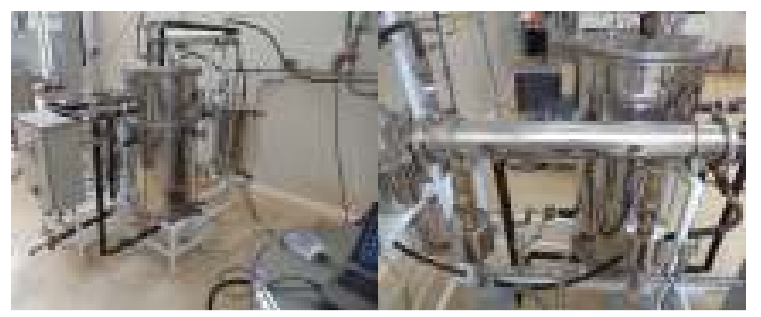

Fig. 1: Experimental equipment of a simple effect evaporator with heat exchanger and vertical tubes

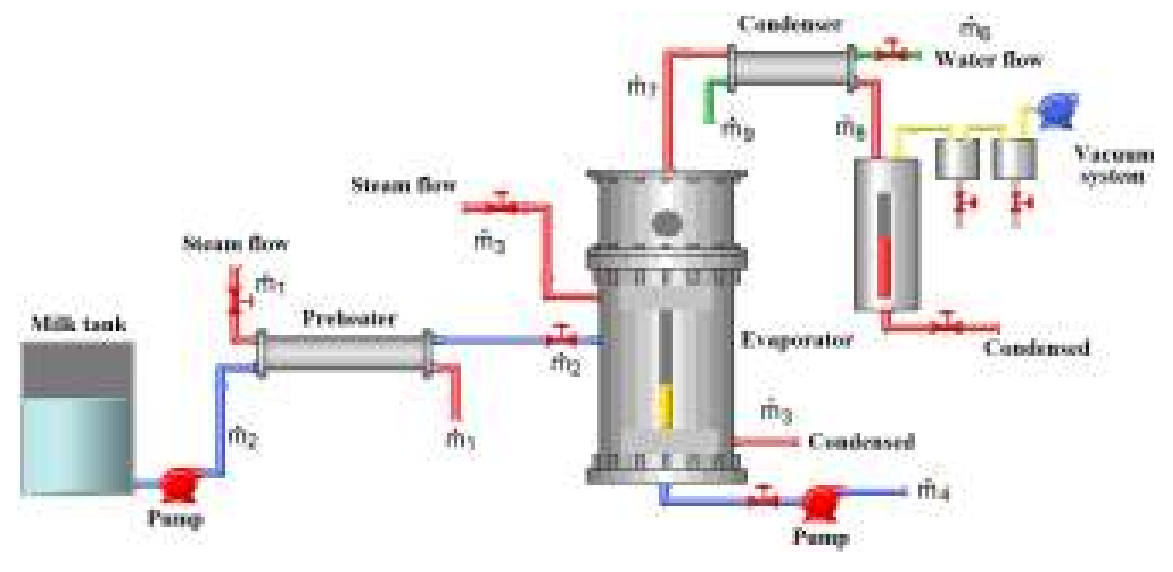

Fig. 2: Process diagram 
out of the system and it is collected for its measurement.

The produced steam in the process goes into a tube heat exchanger with configuration 1-2 in counter-flow, one step in the shell (water) and two steps in the tube (water steam) and condensed when gives its latent heat to the water flow at room temperature. Simultaneously, a membrane pump of the DOSIVAC DD 600 series with variable control, takes the concentrated milk flow that is obtained as a resultant product containing all the solute.

The vacuum of the evaporation chamber, which pressure is 0.3 bar, is done with a pump with a potency of $1 / 8 \mathrm{hp}$ of the series DVR 30 provided with a control system on/off which maintains the pressure in constant value with the expansion dome (up in the column with boiling milk). The equipment has 5 thermocouples for the measurement of feeding temperature (before and after of the preheating), product temperature, the temperature of the produced steam and the temperature of the steam in the tube that goes to the condenser. These thermocouples are plugged into a card for data acquisition of the series NI USB 9211A (National Instruments), which is connected to PC provided with the software Signal Express for DAQ 2011 of LABVIEW 2011. Milk level data are measured with calibrated graduated ruler held by the equipment in the evaporator wall and the solids concentration of evaporated milk was measured with a METTLER TOLEDO QUICK-BRIX 60 refractometer.

The condensed flow, referring to the primary steam and secondary steam, were collected and measured by a test tube. Data from vacuum pressure, feeding flow and product flow were measured by using sensors incorporated into the equipment. Those values were taken directly from the control panel.

Step 2: Propose a modeling hypothesis and set a level of detail for the model according to model object or purpose.

The model would reply to the question: How change the temperature, concentration and level of milk in the evaporator when the pressure of the system, live steam flow and the feeding flow of the milk change in the equipment?

The aim of the model: The aim of the model is to predict the temperatures, concentrations and milk level. This information will allow the model to be used for the control, optimization and estimation of state variables of the evaporation process.

The hypothesis of the model: The milk goes to a preheating system where only heating transfer for convection occurs from the live steam to the system. Then, the milk, almost in the boiling point, goes into the evaporator where the live steam gives caloric energy for convection and starts the evaporation process until total solids are concentrated. The steam that comes from the milk goes out to the upper position of the equipment without taking solids or producing foam. Then, everything is condensed with cooling water in one heat exchanger. During all the process of heat transfer in the system only is observed the mechanism of convection, without taking into consideration the mechanism of radiation and conduction. Besides, the existence of energy loss is not considered from the system to the surrounding environment, due to the presence of insulating material around tubes and equipment. The body of the evaporator is similar to a tube and shell heat exchanger and it is considered that the milk is only a mixture of two components: water and total solids.

Assumptions of the models: For liquids was assumed that the specific heat at constant pressure is equal to the specific heat at constant volume, meaning $\mathrm{C}_{\mathrm{v}}=\mathrm{C}_{\mathrm{p}}$, the hypothesis of perfect mixing is accomplished in the evaporator, the solutes of the milk are non-volatiles, then it is assumed that the steam and the solution are at thermal balance the whole time (Echeverri Ocampo, 2005). Also, it was considered that there is no energy loss to the environment and that there is no chemical reaction during the process. Also, there was the assumption that there was no foam formation during the process (Ordoñez Lugo et al., 2013). Additionally, the following considerations were neglected: the wear of the pipe over time, the thermal resistance by crusting due to deterioration of milk, the heat of solution of the food, the dynamic behavior of the temperature in the tube walls of the preheater, evaporator and condenser, density gradients and temperature in the evaporator and the effects of potential and kinetic energies in the energy balances of process systems.

Step 3: Define as many Process Systems (PS) in the process to be modeled as required by the level of detail set.

In this step, as many Process Systems (PS) on the process to be modeled as required by the level of detail and the relationship of all PS is shown in a block diagram were defined as follows.

In Fig. 3, the proposed processes systems are observed, which were: PS I: side of the evaporator in the preheater, PS II: side feed in the preheater, PS III: side steam in the calandria, PS IV: side food in the calandria, PS V: steam space above the food in the calandria, PS VI: side steam in the condenser and PS VII: side cooling water in the condenser.

Step 4: Apply the principle of conservation on each defined PS.

Given the assumptions set forth in step 2, the principle of conservation (mass and energy) was applied to each of the proposed PS. It is clear that the 


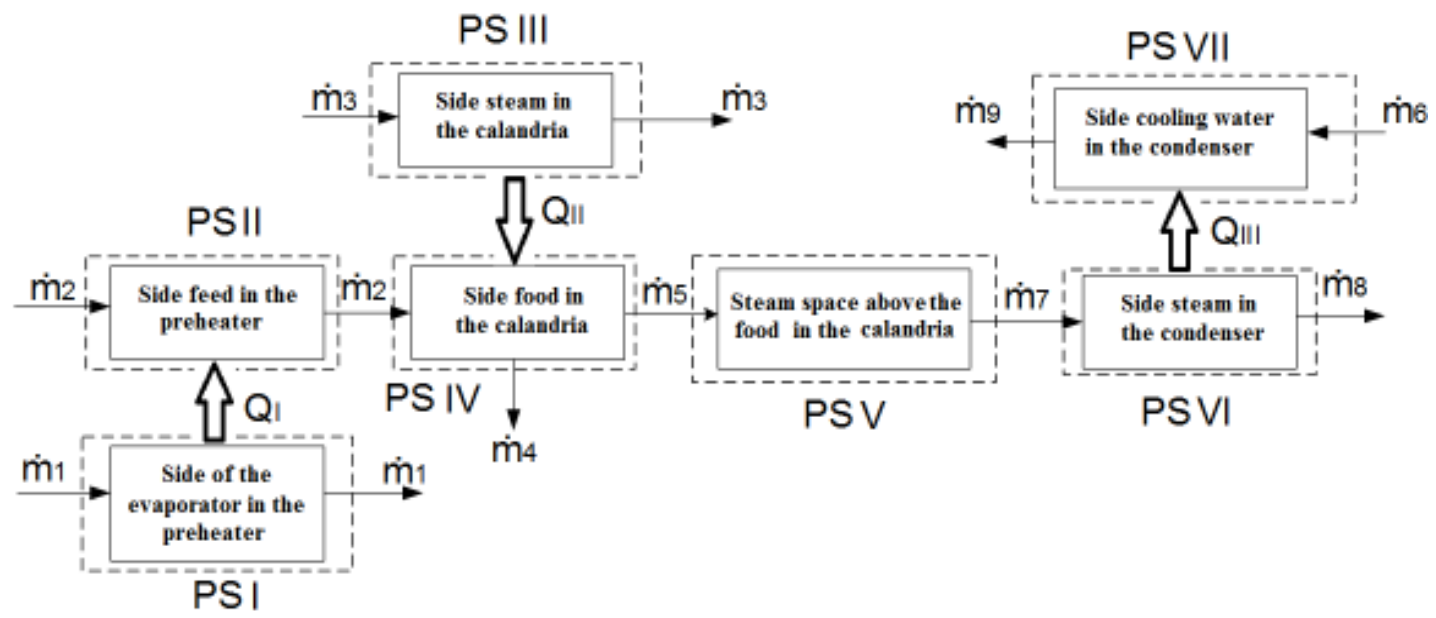

Fig. 3: Block diagram showing process systems

term generation was not used because it is not considered that any chemical reaction occurs inside the evaporator. Thus, the balances were obtained from:

$$
\{\text { Accumulation }\}=\{\text { Inflows }\}-\{\text { Outflows }\}
$$

Then, the material and energy balances obtained in each Process System are:

Process System I (side of steam in the preheater):

Total material balance: Assuming that there is no accumulation was obtained:

$$
\dot{\mathrm{m}}_{1, \mathrm{v}}=\dot{\mathrm{m}}_{1, \mathrm{c}}=\dot{\mathrm{m}}_{1}
$$

Energy balance: Assuming that the steam gets into the process saturated and goes out liquid and condensed, was obtained:

$$
\mathrm{Q}_{\mathrm{I}}=\dot{\mathrm{m}}_{1, \mathrm{v}} \widehat{\mathrm{H}}_{1, \mathrm{v}}-\dot{\mathrm{m}}_{1, \mathrm{c}} \widehat{\mathrm{H}}_{1, \mathrm{c}}=\dot{\mathrm{m}}_{1} \lambda_{\mathrm{v}, 1}
$$

Process system II (side of food in the preheater):

Total material balance: Assuming that there is no accumulation was obtained:

$$
\dot{\mathrm{m}}_{2, \mathrm{i}}=\dot{\mathrm{m}}_{2, \mathrm{o}}=\dot{\mathrm{m}}_{2}
$$

Mass balance for total solids: It is assumed that there is no variation in the concentration of solids:

$$
\mathrm{w}_{2, \mathrm{i}}=\mathrm{w}_{2, \mathrm{o}}=\mathrm{w}_{2}
$$

\section{Energy balance:}

$$
\rho_{2} \mathrm{~V}_{\mathrm{II}} \mathrm{c}_{\mathrm{p}, \mathrm{I}} \frac{\mathrm{dT}_{2}}{\mathrm{dt}}=\dot{\mathrm{m}}_{2} \mathrm{c}_{\mathrm{p}, \mathrm{I}}\left(\mathrm{T}_{2, \mathrm{i}}-\mathrm{T}_{2}\right)+\mathrm{Q}_{\mathrm{I}}
$$

Process system III (side of steam in the calandria): Total material balance: Assuming that there is no accumulation of material was obtained:

$$
\dot{\mathrm{m}}_{3, \mathrm{v}}=\dot{\mathrm{m}}_{3, \mathrm{c}}=\dot{\mathrm{m}}_{3}
$$

Energy balance: Assuming the saturated vapor enters and leaves condensed liquid was obtained:

$$
\mathrm{Q}_{\mathrm{II}}=\dot{\mathrm{m}}_{3, \mathrm{v}} \widehat{\mathrm{H}}_{3, \mathrm{v}}-\dot{\mathrm{m}}_{3, \mathrm{c}} \widehat{\mathrm{H}}_{3, \mathrm{c}}=\dot{\mathrm{m}}_{3} \lambda_{\mathrm{v}, 3}
$$

Process system IV (side food in the calandria): Total material balance:

$$
\frac{\mathrm{dV}_{\mathrm{L}}}{\mathrm{dt}}=\frac{1}{\rho_{4}}\left[\dot{\mathrm{m}}_{2}-\dot{\mathrm{m}}_{4}-\dot{\mathrm{m}}_{5}\right]-\mathrm{V}_{\mathrm{L}} \frac{\mathrm{d} \rho_{4}}{\mathrm{dt}}
$$

Balance total solids: Realizing the balance of total solids balance and replacing in this Eq. (8) was obtained:

$$
\frac{\mathrm{dw}_{4}}{\mathrm{dt}}=\frac{1}{\rho_{4} \mathrm{~V}_{\mathrm{L}}}\left[\left(\mathrm{w}_{2}-\mathrm{w}_{4}\right) \dot{\mathrm{m}}_{2}-\mathrm{w}_{4} \dot{\mathrm{m}}_{5}\right]
$$

\section{Energy balance:}

$$
\rho_{4} \mathrm{~V}_{\mathrm{L}} \mathrm{c}_{\mathrm{p}, 4} \frac{\mathrm{dT}_{4}}{\mathrm{dt}}=\dot{\mathrm{m}}_{2} \widehat{\mathrm{H}}_{2}-\dot{\mathrm{m}}_{5} \widehat{\mathrm{H}}_{5}-\dot{\mathrm{m}}_{4} \widehat{\mathrm{H}}_{4}+\mathrm{Q}_{\mathrm{II}}
$$

Process system V (steam space above the food in the calandria):

Total material balance:

$$
\frac{\mathrm{d}\left[\mathrm{V}_{\mathrm{V}} \rho_{\mathrm{v}, \mathrm{V}}\right]}{\mathrm{dt}}=\dot{\mathrm{m}}_{5}-\dot{\mathrm{m}}_{7}
$$

Besides:

$$
\mathrm{V}_{\mathrm{V}}=\mathrm{V}_{\mathrm{T}}-\mathrm{V}_{\mathrm{L}}
$$

Energy balance:

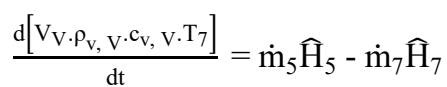


Process system VI (side steam in the condenser):

Total material balance: Assuming that there is no accumulation of material was obtained:

$$
\dot{\mathrm{m}}_{7}=\dot{\mathrm{m}}_{8}
$$

Energy balance: As there is increased boiling point and assuming that $T_{8}$ is the temperature of the liquid in a saturated state it was obtained:

$$
\frac{\mathrm{d}\left[\rho_{8} \cdot \mathrm{c}_{\mathrm{p}, 8} \cdot \mathrm{V}_{\mathrm{VI}} \mathrm{T}_{8}\right]}{\mathrm{dt}}=\dot{\mathrm{m}}_{7} \widehat{\mathrm{H}}_{7}-\dot{\mathrm{m}}_{8} \widehat{\mathrm{H}}_{8}-\mathrm{Q}_{\mathrm{II}}
$$

Process system VII (side cooling liquid in the condenser):

Total material balance: Assuming that there is no accumulation of material was obtained:

$$
\dot{\mathrm{m}}_{6}=\dot{\mathrm{m}}_{9}
$$

Energy balance: Assuming steady state is reached quickly obtained:

$$
\mathrm{Q}_{\mathrm{III}}=\dot{\mathrm{m}}_{6} \widehat{\mathrm{H}}_{6}-\dot{\mathrm{m}}_{9} \widehat{\mathrm{H}}_{9}
$$

Step 5: Select from DBE those equations with significant information to fulfill the model purpose as it was established in step 2.

The DBE (5), (8)-(11), (13) and (15) are the most important and provide all the information on the dynamics of interest in the process. However, these are not resolved regardless of the steady-state Eq. (2), (7) and (17).

Step 6: Identify variables, parameters and constants of the model.

Parameters: $Q_{I}, Q_{I I}, Q_{I I}, \lambda_{v, 1}, \lambda_{v, 3}, \rho_{2}, \rho_{4}, \rho_{8}, \rho_{v, v}$, $\mathrm{c}_{\mathrm{p}, \mathrm{I}}, \mathrm{c}_{\mathrm{p}, 4}, \mathrm{c}_{\mathrm{p}, 8}, \mathrm{c}_{\mathrm{v}, \mathrm{v}}, \widehat{\mathrm{H}}_{2}, \widehat{\mathrm{H}}_{4}, \widehat{\mathrm{H}}_{5}, \widehat{\mathrm{H}}_{6}, \widehat{\mathrm{H}}_{7}, \widehat{\mathrm{H}}_{8}, \widehat{\mathrm{H}}_{9}$.

States: $\mathrm{T}_{2}, \mathrm{~T}_{4}, \mathrm{~T}_{7}, \mathrm{~T}_{8}, \mathrm{w}_{4}, \mathrm{~V}_{\mathrm{L}}$.

Input variables (control actions or disturbances): $\dot{\mathrm{m}}_{1}, \dot{\mathrm{m}}_{2}, \dot{\mathrm{m}}_{3}, \mathrm{~T}_{2, \mathrm{i}}, \mathrm{P}, \dot{\mathrm{m}}_{6}$.

Constants: $\mathrm{w}_{2}, \mathrm{~V}_{\mathrm{II}}, \mathrm{V}_{\mathrm{T}}$

Step 7: Find constitutive equations for calculating the largest number of parameters in each PS. It refers to find the equations for calculating the largest number of parameters in each PS.

Calculation of $Q_{\mathbf{I}}$ : The thermal energy received by the liquid in the preheater $\left(\mathrm{Q}_{\mathrm{I}}\right)$, can be expressed as:

$$
\mathrm{Q}_{\mathrm{I}}=\mathrm{U}_{\mathrm{I}} \cdot \mathrm{A}_{\mathrm{I}} \cdot \Delta \mathrm{T}_{\mathrm{I}}
$$

The area of heat transfer was obtained as follows:

$$
\mathrm{A}_{\mathrm{I}}=\pi \cdot\left(\frac{\mathrm{D}_{\mathrm{i}, \mathrm{I}}+\mathrm{D}_{\mathrm{e}, \mathrm{I}}}{2}\right) \cdot \mathrm{L}_{\mathrm{t}, \mathrm{I}} \cdot \mathrm{N}_{\mathrm{t}, \mathrm{I}}
$$

The global coefficient of heat transference was calculated:

$$
\frac{1}{\mathrm{U}_{\mathrm{I}}}=\frac{1}{\mathrm{~h}_{\mathrm{v}, \mathrm{I}}}+\frac{\mathrm{s}_{\mathrm{w}, \mathrm{I}}}{\mathrm{k}_{\mathrm{w}, \mathrm{I}}}+\frac{1}{\mathrm{~h}_{\mathrm{L}, \mathrm{I}}}
$$

The average temperature difference is calculated in the preheater through the Logarithmic Mean of the Temperature Difference (LMTD):

$$
\Delta T_{I}=\frac{T_{2, i}-T_{2, o}}{\ln \left[\frac{T_{1}-T_{2, i}}{T_{1}-T_{2, o}}\right]}
$$

Film coefficient for the liquid side of the tubes is calculated by the following equation proposed by Kern (1999):

$$
\mathrm{h}_{\mathrm{L}, \mathrm{I}}=\mathrm{j}_{\mathrm{H}, \mathrm{I}} \frac{\mathrm{k}_{\mathrm{L}, \mathrm{I}}}{\mathrm{D}_{\mathrm{i}, \mathrm{I}}}\left(\frac{\mathrm{C}_{\mathrm{p}, \mathrm{I}} \cdot \mu_{\mathrm{L}, \mathrm{I}}}{\mathrm{k}_{\mathrm{L}, \mathrm{I}}}\right)^{1 / 3}\left(\frac{\mu_{\mathrm{L}, \mathrm{I}}}{\mu_{\mathrm{w}, \mathrm{I}}}\right)^{0,14}
$$

where, $\mathrm{j}_{\mathrm{H}, \mathrm{I}}$ was obtained from:

$$
\mathrm{j}_{\mathrm{H}, \mathrm{I}}=10^{0.5066 \log \left(\mathrm{R}_{\mathrm{eL}, \mathrm{I}}\right)-0.2265}
$$

$R_{e L, I}$ is the Reynolds number of the liquid and it is calculated like this:

$$
\mathrm{R}_{\mathrm{eL}, \mathrm{I}}=\frac{\mathrm{D}_{\mathrm{i}, \mathrm{I}} \cdot \mathrm{G}_{\mathrm{t}, \mathrm{I}}}{\mu_{\mathrm{L}, \mathrm{I}}}
$$

$\mathrm{G}_{\mathrm{t}, \mathrm{I}}$ is expressed like:

$$
\mathrm{G}_{\mathrm{t}, \mathrm{I}}=\frac{\dot{\mathrm{m}}_{2}}{\mathrm{a}_{\mathrm{t}, \mathrm{I}}}
$$

$a_{t, I}$ is obtained like this:

$$
\mathrm{a}_{\mathrm{t}, \mathrm{I}}=\frac{\pi}{4} \mathrm{D}_{\mathrm{i}, \mathrm{I}}^{2}
$$

The coefficient of heat transfer for condensing steam: Live steam condenses out of the heat exchanger horizontal tubes, i.e., the side of the shell. The baffles do not affect the condensing film coefficient in exchangers or horizontal condensers since the coefficients are independent of the mass flow of steam (Kern, 1999). The film coefficient for the steam side of the shell is thus calculated according to Kern (1999):

$$
\mathrm{h}_{\mathrm{v}, \mathrm{I}}=1,51\left(\frac{\mathrm{k}_{\mathrm{v}, \mathrm{I}}^{3} \cdot \rho_{\mathrm{v}, \mathrm{I}}^{2} \cdot \mathrm{g}}{4 \cdot \mathrm{G}_{\mathrm{I}}^{\mathrm{v}} \cdot \mu_{\mathrm{v}, \mathrm{I}}}\right)^{1 / 3}
$$

where, $G_{I}^{\prime \prime}$ is calculated like this:

$$
\mathrm{G}_{\mathrm{I}}^{\prime \prime}=\frac{\dot{\mathrm{m}}_{1}}{\mathrm{~L}_{\mathrm{t}, \mathrm{I}} \mathrm{N}_{\mathrm{t}, \mathrm{I}}{ }^{2 / 3}}
$$


Calculation of $\mathbf{Q}_{\mathrm{II}}$ : The thermal energy released by the steam in the calandria $\left(\mathrm{Q}_{\mathrm{II}}\right)$ can be expressed as:

$$
\mathrm{Q}_{\mathrm{II}}=\mathrm{U}_{\mathrm{II}} \cdot \mathrm{A}_{\mathrm{II}} \cdot \Delta \mathrm{T}_{\mathrm{II}}
$$

Overall heat transfer coefficient in the evaporator: The overall resistance to heat transfer between the steam and the boiling liquid is the sum of 5 individual resistance: the resistance of the steam film, the resistance of the internal crusts and outside of the tubes, the resistance of the tube wall and the resistance of boiling liquid. Given that, the resistance of the heating steam is small, it is assumed that there is no crusts or presence of non-condensable gases and the resistance of the tube wall is very small (McCabe et al., 2007), calculating the overall heat transfer coefficient in the evaporator is obtained from the expression (Perry and Green, 2008):

$$
\mathrm{U}_{\mathrm{II}}=\frac{153\left(\Delta \mathrm{T}_{\mathrm{II}}\right)^{0.22}\left(\frac{\mathrm{C}_{\mathrm{p}, 4} \mathrm{\mu}_{4}}{\mathrm{k}_{4}}\right)^{0.4}}{\left(\mathrm{v}_{\mathrm{v}, \mathrm{II}} \mathrm{I}^{-\mathrm{v}_{1, \mathrm{II}}}\right)^{0.37}}
$$

where,

$\mathrm{v}_{\mathrm{v}}$ and $\mathrm{v}_{\mathrm{l}}$ : The specific volumes of steam and boiling the liquid, respectively $\left(\mathrm{m}^{3} / \mathrm{kg}\right)$

Calculation of $\mathbf{Q}_{\text {III }}$ : The thermal energy released by the steam produced ( $\mathrm{Q}_{\text {III }}$ can be expressed as:

$$
\mathrm{Q}_{\mathrm{III}}=\mathrm{U}_{\mathrm{III}} \cdot \mathrm{A}_{\mathrm{III}} \cdot \Delta \mathrm{T}_{\mathrm{III}}
$$

The average temperature difference in the condenser is calculated by the Logarithmic Mean Temperature Difference (LMTD) as follows:

$$
\Delta \mathrm{T}_{\mathrm{III}}=\frac{\mathrm{T}_{6}-\mathrm{T}_{9}}{\ln \left[\frac{\mathrm{T}_{8}-\mathrm{T}_{9}}{\mathrm{~T}_{8}-\mathrm{T}_{6}}\right]}
$$

The global coefficient of heat transfer in the condenser is:

$$
\frac{1}{\mathrm{U}_{\mathrm{III}}}=\frac{1}{\mathrm{~h}_{\mathrm{V}, \text { III }}}+\frac{\mathrm{s}_{\mathrm{W}, \mathrm{III}}}{\mathrm{k}_{\mathrm{w}, \text { III }}}+\frac{1}{\mathrm{~h}_{\mathrm{L}, \text { III }}}
$$

The area of heat transfer in the condenser is expressed as:

$$
\mathrm{A}_{\mathrm{III}}=\pi \cdot\left(\frac{\mathrm{D}_{\mathrm{i}, \text { III }}+\mathrm{D}_{\mathrm{e}, \text { III }}}{2}\right) \cdot \mathrm{L}_{\mathrm{t}, \mathrm{III}} \cdot \mathrm{N}_{\mathrm{t}, \text { III }}
$$

To calculate the coefficient of heat transfer on the side of the shell the following correlation is considered (Kern, 1999):

$$
\mathrm{h}_{\mathrm{L}, \text { III }}=\mathrm{j}_{\mathrm{H}, \mathrm{III}} \frac{\mathrm{k}_{9}}{\mathrm{D}_{\mathrm{i}, \text { III }}}\left(\frac{\mathrm{C}_{\mathrm{p}, 9} \cdot \mu_{9}}{\mathrm{k}_{9}}\right)^{1 / 3}\left(\frac{\mu_{9}}{\mu_{\mathrm{w}, \text { III }}}\right)^{0.14}
$$

Echeverri Ocampo (2005) proposed the following equation for calculating de $\mathrm{j}_{\mathrm{H}, \mathrm{III}}$ :

$$
\mathrm{j}_{\mathrm{H}, \mathrm{III}}=10^{0.5066 \log \left(\mathrm{R}_{\mathrm{eL}, \mathrm{III}}\right)-0.2265}
$$

$\mathrm{R}_{\mathrm{eL}, \text { III }}$ is the Reynolds number of cooling water and it is expressed as follows:

$$
\mathrm{R}_{\mathrm{eL}, \mathrm{III}}=\frac{\mathrm{D}_{\mathrm{eq}, \mathrm{III}} \cdot \mathrm{G}_{\mathrm{a}, \mathrm{III}}}{\mu_{9}}
$$

$G_{a, I I I}$ is expressed as follows:

$$
\mathrm{G}_{\mathrm{a}, \text { III }}=\frac{\dot{\mathrm{m}}_{6}}{\mathrm{a}_{\mathrm{s}, \mathrm{III}}}
$$

The transversal area of the flow for the side of the shell $\mathrm{a}_{\mathrm{s}, \mathrm{III}}$ is determined as follows:

$$
\mathrm{a}_{\mathrm{s}, \mathrm{III}}=\frac{\mathrm{D}_{\mathrm{ic}, \mathrm{III}} \cdot \mathrm{C}_{\mathrm{III}}^{\prime} \cdot \mathrm{B}_{\mathrm{III}}}{\mathrm{P}_{\mathrm{T}, \mathrm{III}}}
$$

The equivalent diameter of the shell $\left(\mathrm{D}_{\mathrm{eq}, \mathrm{III}}\right)$, for a triangular arrangement, is calculated by the following equation (Cao, 2010):

$$
\mathrm{D}_{\mathrm{eq}, \text { III }}=\frac{4 \cdot\left(0.43 \cdot \mathrm{P}_{\mathrm{T}, \mathrm{III}}^{2}-0.125 \cdot \pi \cdot \mathrm{D}_{\mathrm{e}, \text { III }}^{2}\right)}{0.5 \cdot \pi \cdot \mathrm{D}_{\mathrm{e}, \text { III }}}
$$

The steam produced in the evaporator is condensed in horizontal tubes condenser. Kern (1999) proposes the following correlation for condensation in horizontal tubes:

$$
\mathrm{h}_{\mathrm{v}, \text { III }}=1.51\left(\frac{\mathrm{k}_{\mathrm{V}}^{3}, \mathrm{III} \cdot \mathrm{\rho}_{\mathrm{V}, \text { III }}^{2} \mathrm{~g}}{4 \cdot \mathrm{G}_{\mathrm{III}} \cdot \mu_{\mathrm{v}, \text { III }}}\right)^{1 / 3}
$$

where, $G_{\text {III }}^{\prime \prime}$ is calculated as follows:

$$
\mathrm{G}_{\mathrm{III}}^{\prime \prime}=\frac{\dot{\mathrm{m}}_{7}}{\mathrm{~L}_{\mathrm{t}, \mathrm{III}} \cdot \mathrm{N}_{\mathrm{t}, \mathrm{III}}}
$$

Temperature and saturation pressure: To find the relationship between the pressure and the saturation temperature of the pure water, the equation developed by Wagner was used (Poling et al., 2001).

Enthalpy: It was taken as a reference point for the enthalpy changes $T_{o}=273.15 \mathrm{~K}$ and $P_{o}=100 \mathrm{kPa}$. The effect of pressure on the enthalpy was discarded (Poling et al., 2001; Smith et al., 2007).

For enthalpy changes associated only to sensible heat (in which there is no phase change), the enthalpy is expressed as: 


$$
\widehat{H}=\int_{T_{0}}^{T} C_{p}(T) d T
$$

For the enthalpy changes associated with phase changes the following equation (Ibarz and BarbosaCanovas, 2005) was used:

$$
\widehat{\mathrm{H}}=\int_{\mathrm{T}_{\mathrm{o}}}^{\mathrm{T}} \mathrm{C}_{\mathrm{p}}(\mathrm{T}) \mathrm{dT}+\lambda_{\mathrm{v}}(\mathrm{T})
$$

The vaporization enthalpy, $\lambda_{\mathrm{v}}(\mathrm{kJ} / \mathrm{kg})$, of a pure liquid was determined using the equation given by Pitzer (Poling et al., 2001).

\section{Density:}

For saturated steam: The molar density is the inverse of the molar volume and for a gas or steam the molar volume can be estimated with a state equation. It should be noted that water is a polar substance. To calculate vapor-liquid equilibrium of polar pure fluid and nonpolar pure fluids, the following cubic equation is used (Echeverri Ocampo, 2005):

$$
P=\frac{R T\left(1+k_{1} b / v\right)}{v-k_{2} b}-\frac{a}{v(v+c)}
$$

The method for calculating the values of the constants $\mathrm{k}_{1}, \mathrm{k}_{2}, \mathrm{a}, \mathrm{b}$ and $\mathrm{c}$ is developed in Echeverri Ocampo (2005).

For the saturated liquid water: To estimate the molar volume of saturated liquid and therefore the molar density $\left(\rho_{1}=1 / \mathrm{v}_{1}\right)$, equation Rackett was used (Poling et al., 2001; Smith et al., 2007).

For milk: The used model depends on the temperature and the solids concentration (Paramalingam, 2004):

$$
\rho_{\text {milk }}=1002-0.311 \mathrm{~T}+3.78(\% \mathrm{w} / \mathrm{w})
$$

where,

$\rho_{\text {milk }}\left(\mathrm{kg} / \mathrm{m}^{3}\right)$ : Milk density

$\mathrm{T}\left({ }^{\circ} \mathrm{C}\right) \quad:$ The temperature

$\%(\mathrm{w} / \mathrm{w}) \quad$ : The content of total solids expressed in percentage

\section{Thermal conductivity:}

For milk: Paramalingam (2004) has the following expression of conductivity, $\mathrm{k}_{\text {milk }}(\mathrm{W} / \mathrm{m} \mathrm{K})$, depending on the temperature, $\mathrm{T}\left({ }^{\circ} \mathrm{C}\right)$ and $\%(\mathrm{w} / \mathrm{w})$ is the total solids content expressed as a percentage:

$$
\mathrm{k}_{\text {milk }}=0.584+0.00119 \cdot \mathrm{T}-0.00343(\% \mathrm{w} / \mathrm{w})
$$

For the liquid water: The thermal conductivity can be estimated like this:

$$
\mathrm{k}_{\mathrm{a}}=0.100+0.00166 \mathrm{~T}
$$

$\mathrm{k}_{\mathrm{a}}$ : Expressed in $\mathrm{W} / \mathrm{mK}$ and $\mathrm{T}$ in $\mathrm{K}$ (Figura and Teixeira, 2007)
Specific heat:

For the liquid water: Rahman (2009) proposed the following expression:

$$
\mathrm{C}_{\mathrm{pa}}=4176.2-0.090864 \mathrm{~T}+0.0054731 \mathrm{~T}^{2}
$$

$\mathrm{C}_{\mathrm{pa}}$ : Expressed in $\mathrm{J} / \mathrm{kg} \mathrm{K}$ and the temperature is $\mathrm{T}\left({ }^{\circ} \mathrm{C}\right)$

For milk, Erdoğdu (2009) proposed the following equation:

$$
\mathrm{Cp}_{\text {milk }}=4184-2686 \%(\mathrm{w} / \mathrm{w})
$$

$\mathrm{Cp}_{\text {milke }}$ : Expressed in $\mathrm{J} / \mathrm{kg} \mathrm{K}$ and the content of total solids is expressed in percentage

Viscosity:

For liquid water: Echeverri Ocampo (2005) proposes the following equation, which is valid for temperatures between 0 and $370^{\circ} \mathrm{C}$ :

$$
\mu_{\mathrm{a}}=0.001 \mathrm{e}^{\left(-24.71+4209 \mathrm{~T}^{-1}+0.04527 \mathrm{~T}-0.00003376 \mathrm{~T}^{2}\right)}
$$

$\mu_{\mathrm{a}}$ : Expressed in $\mathrm{kg} / \mathrm{ms}$ and $\mathrm{T}$ in $\mathrm{K}$

For milk: Paramalingam (2004) presents the following expression of milk viscosity, $\mu_{\text {milk }}$ (in centipoise), depending on the temperature, $\mathrm{T}\left({ }^{\circ} \mathrm{C}\right)$ and $\%(\mathrm{w} / \mathrm{w})$ is the total solids content expressed as a percentage:

$$
\mu_{\text {milk }}=1.099+\frac{0.2371}{\left(1-\frac{\%(w / w)}{100}\right)^{9.836}} \mathrm{e}^{-0.03827 \mathrm{~T}}
$$

Boiling point elevation $\left(\Delta \mathbf{T}_{\text {epe }}\right)$ for milk: Franco (2007) proposes the following expression:

$\Delta \mathrm{T}_{\text {epe }}\left({ }^{\circ} \mathrm{C}\right)=3.5714(\% \mathrm{w} / \mathrm{w})^{2}+1.9643(\% \mathrm{w} / \mathrm{w})+0.0393$

where,

$\%(\mathrm{w} / \mathrm{w})$ : The total solids content expressed as a percentage

Boiling liquid volume: From the geometry and dimensions of the evaporator, the equation expressing the volume of liquid $\left(\mathrm{m}^{3}\right)$ depending on the level, L (m), was obtained:

$$
\mathrm{V}_{\mathrm{L}}=0.008+0.02331 \mathrm{~L}
$$

Step 8: Verify the Degree of Freedom (DF) of the model.

The final PBSM is constituted by the differential Eq. (5), (8)-(11), (13) and (15) and the constitutive Eq. (18), (29), (31) and (43)-(54) plus Wagner equation and Rackett model. All this added 28 equations 
necessary. The model contains 28 unknowns: the states $\mathrm{T}_{2}, \mathrm{~T}_{4}, \mathrm{~T}_{7}, \mathrm{~T}_{8}, \mathrm{w}_{4}$ and $\mathrm{L}$; heat transfer rate represented in $\mathrm{Q}_{\mathrm{I}}, \mathrm{Q}_{\mathrm{II}}$ and $\mathrm{Q}_{\mathrm{II}}$; thermodynamic properties $\lambda_{\mathrm{V}, 1}, \lambda_{\mathrm{V}, 3}$, $\rho_{2}, \rho_{4}, \rho_{8}, \rho_{\mathrm{v}, \mathrm{V}}, \mathrm{c}_{\mathrm{p}, \mathrm{I}}, \mathrm{c}_{\mathrm{p}, 4}, \mathrm{c}_{\mathrm{p}, 8}, \mathrm{c}_{\mathrm{v}, \mathrm{V}}, \widehat{\mathrm{H}}_{2}, \widehat{\mathrm{H}}_{4}, \widehat{\mathrm{H}}_{5}, \widehat{\mathrm{H}}_{6}, \widehat{\mathrm{H}}_{7}$, $\widehat{\mathrm{H}}_{8}$ and $\widehat{\mathrm{H}}_{9}$; the mass flow of evaporator outlet $\left(\dot{\mathrm{m}}_{4}\right)$ and the mass flow of condensed milk extracted from the condenser outlet $\left(\dot{\mathrm{m}}_{8}\right)$. Therefore, the model is consistent with $\mathrm{GL}=$ \#Equations - \# Unknowns $=0$.

Step 9: Build a computational model.

The differential and algebraic equations were resolved with LabVIEW 2011®, using the Runge-Kutta method of fourth order with step $0.01 \mathrm{~min}$. The different conditions for the simulation were determined to look to assist in validating the model, as discussed in Step 10.

Step 10: Validate the model response using real operating conditions related to those used at step 2 to establish the objective of the model.

The model simulation and experimental runs taking into account the following design features and equipment operation was performed: Evaporator feed temperature: 35 to 70 ; saturation pressure of the live steam: 5 to 15 psig; minimum vacuum pressure: 0.3 bar; Evaporator body height: $0.82 \mathrm{~m}$; Evaporator diameter: $0.45 \mathrm{~m}$; number of tubes: 30 tubes in triangular arrangement plus a central return tube; short tubes inner diameter: $0.0254 \mathrm{~m}$; outer diameter short tubes: $0.03216 \mathrm{~m}$; Central diameter return tube: 0.1016 $\mathrm{m}$; tube wall thickness: $0.00338 \mathrm{~m}$; calandria tubes length: $0.42 \mathrm{~m}$.

For model validation step type disturbance in the corresponding variables were applied to the inflow supply milk to the evaporator, vacuum pressure in the evaporation chamber and flow of live steam in the evaporator calandria. This allowed knowing the dynamic temperature behavior, concentration and column level in the boiling liquid within the evaporator. Disturbances were applied with varying duration and magnitude. In Fig. 4 to 6 the type perturbations step of vacuum pressure, steam flow and feed flow is applied to the process.

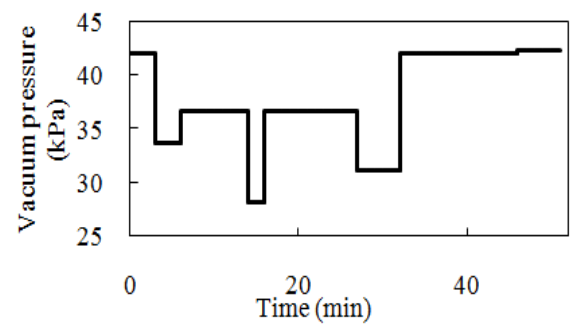

Fig. 4: Perturbations in the vacuum pressure

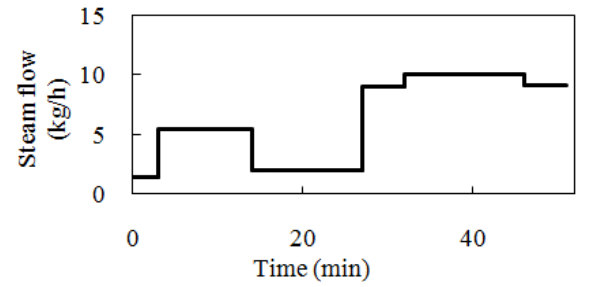

Fig. 5: Perturbations in the steam flow

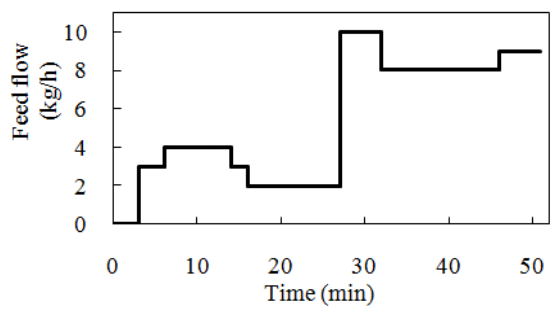

Fig. 6: Perturbations of the feeding flow of the milk

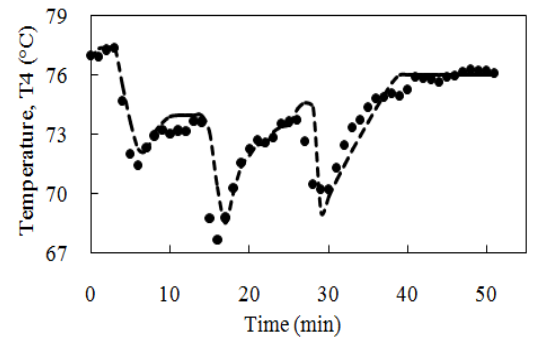

Fig. 7: Dynamic of milk temperature

Dashed line: Simulated data; Dots: Experimental data

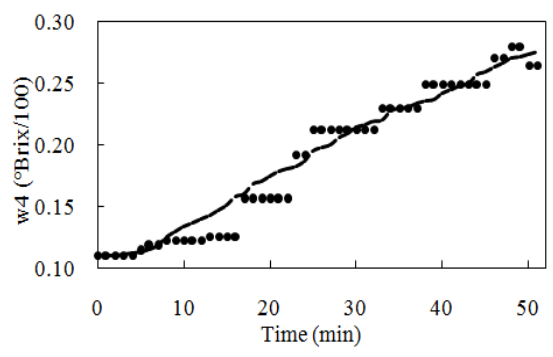

Fig. 8: Dynamic of total solids concentration in milk

Dashed line: Simulated data; Dots: Experimental data

In Fig. 7 to 9, the dots represent the experimental data and the dashed line represents the simulated results for the three response variables of interest, temperature and concentration level of milk in the evaporator model. It is observed that the behavior of real and simulated values is very similar, i.e., the model responds very similarly to the response of the experimental equipment to the perturbations caused to the input variables.

Additionally, the mean error index calculated for each measured variable is 0.655 for the milk temperature in the evaporator, 0.004 for the level of milk in the evaporator and 0.009 for the total solids concentration of the concentrated milk, i.e., that the 


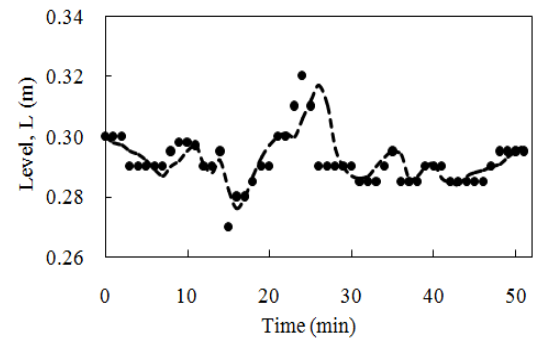

Fig. 9: Dynamic of milk level in the evaporator

Dashed line: Simulated data; Dots: Experimental data

percentage of error between the model values and values of the experimental data of the measured variables are less than $5 \%(0.89,1.30$ and $4.84 \%$, respectively). This means that the proposed model for the evaporation process of milk has a good predictive ability and even some descriptive of the phenomena occurring and, for simplicity of differential equations that comprise it, it has useful features in optimization, estimation of states variables and process control.

Ordoñez et al. (2012) obtained results of the concentration of solids with a margin of error of $15 \%$, which indicates that the evaporation model proposed in this study has greater precision than said model because the errors do not exceed 5\%. Shah and Bhagchandani (2012) and Franco (2007) propose a static model of evaporation, while the evaporation model proposed in this study is dynamic, which is useful for process control. On the other hand, Russell et al. (2000) propose an evaporation model with constant global heat transfer coefficients, while in this study the proposed model considered the variation of this coefficient with respect to temperature and solids concentration, which reduced the error between the experimental data and the simulated data.

\section{CONCLUSION}

A phenomenological based semi-physical model for the evaporation process of milk in a simple effect evaporator was developed. Because of its simplicity, the model can be used in process control, in the estimation of states and optimization.

Simulation and quantitative validation showed that the model proposed for the evaporation process of milk has a good predictive ability and even some descriptive of the phenomena occurring. Therefore, in order to predict the temperature, concentration and level of milk within the evaporator tank, the aim was achieved.

\section{ACKNOWLEDGMENT}

The authors express their gratitude to the Laboratory of Applied Engineering at Universidad de Córdoba (Colombia) for the financial support for this study.

\section{CONFLICT OF INTEREST}

The manuscript was prepared and reviewed with the participation of all authors, who declare that there is no conflict of interests in the present work.

\section{NOMENCLATURE}

$\mathrm{a}_{\mathrm{t}, \mathrm{I}}$ : Cross-sectional flow area of the preheater tubes $\left[\mathrm{m}^{2}\right]$

$\mathrm{a}_{\mathrm{S}, \text { III }}$ : Transverse flow area to the side of the shell $\left[\mathrm{m}^{2}\right]$

$\mathrm{A}_{\mathrm{I}}: \quad$ Heat transfer area in the preheater $\left[\mathrm{m}^{2}\right]$

$\mathrm{A}_{\mathrm{II}}$ : Heat transfer area in the evaporator $\left[\mathrm{m}^{2}\right]$

$\mathrm{A}_{\mathrm{III}}$ : Heat transfer area in the condenser $\left[\mathrm{m}^{2}\right]$

$\mathrm{B}_{\mathrm{III}}$ : Spacing of the baffles of shell condenser [m]

$\mathrm{c}_{\mathrm{p}, \mathrm{I}}$ : Specific heat at constant pressure of the milk in the preheater $\left[\mathrm{kJ} / \mathrm{kg}^{\circ} \mathrm{C}\right]$

$c_{p, 4}$ : Specific heat at constant pressure in the evaporator milk $\left[\mathrm{kJ} / \mathrm{kg}^{\circ} \mathrm{C}\right]$

$\mathrm{c}_{\mathrm{p}, 8}$ : Specific heat at constant pressure of the liquid at the condenser outlet $\left[\mathrm{kJ} / \mathrm{kg}^{\circ} \mathrm{C}\right]$

$\mathrm{c}_{\mathrm{p}, 9}$ : Specific heat at constant pressure of the cooling water to the condenser outlet $\left[\mathrm{kJ} / \mathrm{kg}^{\circ} \mathrm{C}\right]$

$\mathrm{c}_{\mathrm{v}, \mathrm{V}}$ : Specific heat at constant volume of extracted steam of the milk in the evaporator $\left[\mathrm{kJ} / \mathrm{kg}^{\circ} \mathrm{C}\right]$

$\mathrm{C}_{\text {III }}^{\prime}$ : Shortest distance between the walls of two adjacent tubes of the condenser [m]

$\mathrm{D}_{\mathrm{i}, \mathrm{I}}$ : Internal diameter of the tubes in the preheater [m]

$\mathrm{D}_{\mathrm{e}, \mathrm{I}}$ : External diameter of the tubes in the preheater [m]

$\mathrm{D}_{\mathrm{i}, \text { III }}$ : Internal diameter of the tubes in the condenser $[\mathrm{m}]$

$\mathrm{D}_{\mathrm{e}, \mathrm{III}}:$ External diameter of the tubes in the condenser [m]

$\mathrm{D}_{\mathrm{eq}, \mathrm{III}}$ : Equivalent diameter of the shell condenser [m]

$\mathrm{D}_{\mathrm{ic}, \text { III }}$ : Internal diameter of the condenser shell [m]

g: $\quad$ Acceleration of gravity $=9,8 \mathrm{~m} / \mathrm{s}^{2}$

$\mathrm{h}_{\mathrm{L}, \mathrm{I}}$ : Convective heat transfer coefficient on the side of the preheater milk $\left[\mathrm{W} / \mathrm{m}^{2 \circ} \mathrm{C}\right]$

$\mathrm{h}_{\mathrm{v}, \mathrm{I}}$ : Convective heat transfer coefficient from the side of steam in the preheater $\left[\mathrm{W} / \mathrm{m}^{2 \circ} \mathrm{C}\right]$

$h_{L, ~ I I I}$ : Convective heat transfer coefficient from the side of the cooling water in the condenser $\left[\mathrm{W} / \mathrm{m}^{2 \circ} \mathrm{C}\right]$

$\mathrm{h}_{\mathrm{v}, \text { III }}$ : Convective heat transfer coefficient from the side of steam in the condenser $\left[\mathrm{W} / \mathrm{m}^{2 \circ} \mathrm{C}\right]$

$\widehat{\mathrm{H}}_{1, \mathrm{v}}$ : Enthalpy of the live steam entering the preheater $[\mathrm{kJ} / \mathrm{kg}]$

$\widehat{\mathrm{H}}_{1, \mathrm{c}}$ : Enthalpy of condensate leaving the preheater $[\mathrm{kJ} / \mathrm{kg}]$

$\widehat{\mathrm{H}}_{2}$ : $\quad$ Milk enthalpy entering the evaporator $[\mathrm{kJ} / \mathrm{kg}]$

$\widehat{\mathrm{H}}_{3, \mathrm{v}}$ : Live steam enthalpy entering the evaporator calandria $[\mathrm{kJ} / \mathrm{kg}]$ 
$\widehat{\mathrm{H}}_{3, \mathrm{c}}$ : Enthalpy of condensate leaving the evaporator calandria $[\mathrm{kJ} / \mathrm{kg}]$

$\widehat{\mathrm{H}}_{4}$ : Enthalpy of concentrated milk leaving the evaporator $[\mathrm{kJ} / \mathrm{kg}]$

$\widehat{\mathrm{H}}_{5}$ : Enthalpy of steam extracted of the milk that goes to the upper chamber of the evaporator $[\mathrm{kJ} / \mathrm{kg}]$

$\widehat{\mathrm{H}}_{6}$ : Enthalpy of cooling water entering the condenser $[\mathrm{kJ} / \mathrm{kg}]$

$\widehat{\mathrm{H}}_{7}$ : Steam enthalpy extracted milk leaving the evaporator $[\mathrm{kJ} / \mathrm{kg}]$

$\widehat{\mathrm{H}}_{8}$ : Enthalpy of condensate leaving the condenser $[\mathrm{kJ} / \mathrm{kg}]$

$\widehat{\mathrm{H}}_{9}$ : Enthalpy of the cooling water leaving the condenser $[\mathrm{kJ} / \mathrm{kg}]$

$\mathrm{k}_{\mathrm{w}, \mathrm{I}}$ : Thermal conductivity of preheater tubes $\left[\mathrm{W} / \mathrm{m}^{\circ} \mathrm{C}\right]$

$\mathrm{k}_{\mathrm{w}, \text { III }}$ : Thermal conductivity of the condenser tubes $\left[\mathrm{W} / \mathrm{m}^{\circ} \mathrm{C}\right]$

$\mathrm{k}_{\mathrm{L}, \mathrm{I}}$ : Thermal conductivity of milk in the preheater $\left[\mathrm{W} / \mathrm{m}^{\circ} \mathrm{C}\right]$

$\mathrm{k}_{\mathrm{v}, \mathrm{I}}$ : Thermal conductivity of steam in the preheater $\left[\mathrm{W} / \mathrm{m}^{\circ} \mathrm{C}\right]$

$\mathrm{k}_{4}$ : Thermal conductivity of the milk in the evaporator $\left[\mathrm{W} / \mathrm{m}^{\circ} \mathrm{C}\right]$

$\mathrm{k}_{9}$ : Thermal conductivity of cooling water to the condenser outlet $\left[\mathrm{W} / \mathrm{m}^{\circ} \mathrm{C}\right]$

L: $\quad$ Milk level in the evaporator $\left[\mathrm{m}^{3}\right]$

$\mathrm{L}_{\mathrm{t}, \mathrm{I}}: \quad$ Tube length of preheater $[\mathrm{m}]$

$\mathrm{L}_{\mathrm{t}, \text { IIII }}$ : Length of the condenser tubes [m]

$\dot{\mathrm{m}}_{1, \mathrm{v}}$ : Live steam mass flow entering into the preheater $[\mathrm{kg} / \mathrm{h}]$

$\dot{\mathrm{m}}_{1, \mathrm{c}}$ : Condensate mass flow leaving the preheater $[\mathrm{kg} / \mathrm{h}]$

$\dot{\mathrm{m}}_{2, \mathrm{i}}$ : Mass flow of milk entering into the preheater $[\mathrm{kg} / \mathrm{h}]=\dot{m}_{2}$

$\dot{\mathrm{m}}_{2, \mathrm{o}}$ : Mass flow of milk leaving the preheater $[\mathrm{kg} / \mathrm{h}]$ $=\dot{m}_{2}$

$\dot{\mathrm{m}}_{3, \mathrm{v}}$ : Live steam mass flow entering the evaporator calandria $[\mathrm{kg} / \mathrm{h}]=\dot{m}_{3}$

$\dot{\mathrm{m}}_{3, \mathrm{c}}$ : Condensate mass flow leaving into the evaporator calandria $[\mathrm{kg} / \mathrm{h}]=\dot{m}_{3}$

$\dot{\mathrm{m}}_{4}$ : Mass flow of concentrated milk leaving the evaporator $[\mathrm{kg} / \mathrm{h}]$

$\dot{\mathrm{m}}_{5}$ : Mass flow of steam extracted of the milk in the evaporator $[\mathrm{kg} / \mathrm{h}]$

$\dot{\mathrm{m}}_{6}$ : Mass flow of cooling water entering the condenser $[\mathrm{kg} / \mathrm{h}]$

$\dot{\mathrm{m}}_{7}$ : Mass flow of steam from the upper chamber evaporator $[\mathrm{kg} / \mathrm{h}]$

$\dot{\mathrm{m}}_{8}$ : Mass flow of condensate from the condenser $[\mathrm{kg} / \mathrm{h}]=\dot{m}_{7}$

$\dot{\mathrm{m}}_{9}$ : Mass flow of cooling water leaving the condenser $[\mathrm{kg} / \mathrm{h}]=\dot{m}_{6}$

$\mathrm{N}_{\mathrm{t}, \mathrm{I}}: \quad$ Number of tubes in the preheater

$\mathrm{N}_{\mathrm{t}, \mathrm{III}}:$ Number of tubes in the condenser
$\mathrm{P}_{\mathrm{T}, \mathrm{III}}: \quad$ Spacing between condenser tubes $[\mathrm{m}]$

$\mathrm{Q}_{\mathrm{I}}$ : $\quad$ Heat transfer rate in the preheater [W]

$\mathrm{Q}_{\mathrm{II}}$ : Heat transfer rate in the calandria evaporator [W]

$\mathrm{Q}_{\mathrm{III}}: \quad$ Heat transfer rate in the condenser [W]

R: $\quad$ Constant for ideal gas, $8.314[\mathrm{~J} / \mathrm{molK}]$

$\mathrm{s}_{\mathrm{w}, \mathrm{I}}$ : Thickness of the tubes of the preheater [m]

$\mathrm{s}_{\mathrm{w}, \mathrm{III}}$ : Thickness of tubes of the condenser [m]

$\mathrm{T}_{1}$ : $\quad$ Live steam temperature in the preheater $\left[{ }^{\circ} \mathrm{C}\right]$

$\mathrm{T}_{2, \mathrm{i}}$ : $\quad$ Milk temperature entering in the preheater $\left[{ }^{\circ} \mathrm{C}\right]$

$\mathrm{T}_{2, \mathrm{o}}$ : $\quad$ Milk temperature leaving the preheater $\left[{ }^{\circ} \mathrm{C}\right]=$ $T_{2}$

$\mathrm{T}_{4}$ : Concentrated milk temperature leaving the evaporator $\left[{ }^{\circ} \mathrm{C}\right]$

$\mathrm{T}_{6}$ : Cooling water temperature entering the condenser $\left[{ }^{\circ} \mathrm{C}\right]$

$\mathrm{T}_{7}$ : Temperature of extracted steam of concentrated milk leaving the evaporator $\left[{ }^{\circ} \mathrm{C}\right]$

$\mathrm{T}_{8}$ : $\quad$ Liquid temperature leaving the condenser $\left[{ }^{\circ} \mathrm{C}\right]$

$\mathrm{T}_{9}$ : Cooling water temperature leaving the condenser $\left[{ }^{\circ} \mathrm{C}\right]$

$\mathrm{U}_{\mathrm{I}}$ : Overall heat transfer coefficient in the preheater $\left[\mathrm{W} / \mathrm{m}^{2 \circ} \mathrm{C}\right]$

$\mathrm{U}_{\mathrm{II}}$ : Overall heat transfer coefficient in the evaporator $\left[\mathrm{W} / \mathrm{m}^{2 \circ} \mathrm{C}\right]$

$\mathrm{U}_{\mathrm{III}}$ : Overall heat transfer coefficient in the condenser $\left[\mathrm{W} / \mathrm{m}^{2 \circ} \mathrm{C}\right]$

$\mathrm{V}_{\mathrm{II}}: \quad$ Volume of milk in the preheater $\left[\mathrm{m}^{3}\right]$

$\mathrm{V}_{\mathrm{VI}}$ : Volume of the condenser where the vapor extracted from the milk is condensed $\left[\mathrm{m}^{3}\right]$

$\mathrm{V}_{\mathrm{L}}$ : Volume of milk concentrated in the evaporator $\left[\mathrm{m}^{3}\right]$

$\mathrm{V}_{\mathrm{V}}$ : Volume of the steam chamber above the concentrated milk in the evaporator $\left[\mathrm{m}^{3}\right]$

$\mathrm{V}_{\mathrm{T}}$ : Total volume within the evaporator $\left[\mathrm{m}^{3}\right]$

$\mathrm{w}_{2, \mathrm{i}}$ : Weight fraction of total solids of milk entering the preheater

$\mathrm{w}_{2, \mathrm{o}}$ : Weight fraction of total solids of the milk leaving the preheater $=w_{2}$

$\mathrm{w}_{4}$ : Weight fraction of total solids of the concentrated milk leaving the evaporator

\section{Greek symbols:}

$\rho_{2}$ : Average density of the milk in the preheater outlet $\left[\mathrm{kg} / \mathrm{m}^{3}\right]$

$\rho_{4}$ : Density of concentrated milk in the evaporator $\left[\mathrm{kg} / \mathrm{m}^{3}\right]$

$\rho_{8}$ : Density of the liquid leaving the condenser $\left[\mathrm{kg} / \mathrm{m}^{3}\right]$

$\rho_{\mathrm{v}, \mathrm{I}}: \quad$ Vapor density in the preheater $\left[\mathrm{kg} / \mathrm{m}^{3}\right]$

$\rho_{\mathrm{v}, \mathrm{V}}$ : Vapor density in the chamber above the concentrated milk in the evaporator $\left[\mathrm{kg} / \mathrm{m}^{3}\right]$

$\lambda_{\mathrm{v}, 1}$ : Vaporization heat of the steam entering into the preheater $[\mathrm{kJ} / \mathrm{kg}]$

$\lambda_{\mathrm{v}, 3}$ : Vaporization heat of the steam entering the calandria evaporator $[\mathrm{kJ} / \mathrm{kg}]$ 
$\Delta \mathrm{T}_{\mathrm{I}}$ : Log mean temperature difference in the preheater $\left[{ }^{\circ} \mathrm{C}\right]$

$\Delta \mathrm{T}_{\mathrm{II}}$ : Log mean temperature difference in the evaporator $\left[{ }^{\circ} \mathrm{C}\right]$

$\Delta \mathrm{T}_{\mathrm{III}}$ : Log mean temperature difference in the condenser $\left[{ }^{\circ} \mathrm{C}\right]$

$\mu_{\mathrm{L}, \mathrm{I}}: \quad$ Milk average absolute viscosity in the preheater $[\mathrm{kg} / \mathrm{m} \mathrm{s}]$

$\mu_{\mathrm{w}, \mathrm{I}}$ : Dynamic viscosity of milk evaluated at wall temperature of the tubes in preheater $[\mathrm{kg} / \mathrm{m} \mathrm{s}]$

$\mu_{\mathrm{w} \text {, III }}$ : Dynamic viscosity of the cooling water to the wall temperature of the tubes in the condenser $[\mathrm{kg} / \mathrm{m} \mathrm{s}]$

$\mu_{\mathrm{v}, \mathrm{I}}$ : Dynamic viscosity of the steam in the preheater $[\mathrm{kg} / \mathrm{m} \mathrm{s}]$

$\mu_{4}$ : $\quad$ Dynamic viscosity of the milk in the evaporator $[\mathrm{kg} / \mathrm{m} \mathrm{s}]$

$\mu_{9}$ : Dynamic viscosity of the cooling water to the condenser outlet $[\mathrm{kg} / \mathrm{m} \mathrm{s}]$

\section{REFERENCES}

Álvarez, H., R. Lamanna, P. Vega and S. Revollar, 2009. Metodología para la Obtención de Modelos Semifísicos de Base Fenomenológica Aplicada a una Sulfitadora de Jugo de Caña de Azúcar. Rev. Iberoam. Automát. Inform. Ind., 6(3): 10-20.

Cao, E., 2010. Heat Transfer in Process Engineering. 1st Edn., McGraw-Hill, New York.

Echeverri Ocampo, V., 2005. Control de los Evaporadores de los Laboratorios de Procesos Productivos de la Universidad Nacional de Colombia sede manizales. M.Sc. Thesis, National University of Colombia, Manizales, Caldas.

Erdoğdu, F., 2009. Optimization in Food Engineering. CRC Press Taylor and Francis Group, New York.

Figura, L.O. and A.A. Teixeira, 2007. Food Physics: Physical Properties - Measurement and Application.1st Edn., Springer, Berlin, London.

Franco, I.J.A., 2007. Diseño de un Simulador por Computadora de Procesos de Evaporación en una Línea de Evaporadores de Múltiple Efecto. Bol. Electrón., 4: 1-16.
Ibarz, A. and G.V. Barbosa-Canovas, 2005. Operaciones Unitarias en la Ingeniería de Alimentos. Mundi-Prensa, Madrid.

Kern, D., 1999. Procesos de Transferencia de Calor. 31st Edn., CECSA, México D.F.

McCabe, W.L., J.C. Smith and P. Harriot, 2007. Operaciones unitarias en ingeniería química. McGraw-Hill, México, D.F.

Miranda, V. and R. Simpson, 2005. Modelling and simulation of an industrial multiple effect evaporator: Tomato concentrate. J. Food Eng., 66(2): 203-210.

Ordoñez, R.A., C.A. Hernández and L.F. Pedraza, 2012. Modelado de un sistema de evaporación de múltiple efecto para la producción de panela (Azúcar no Centrifugado). Inf. Tecnol., 23(6): 105120.

Ordoñez Lugo, R.A., F. Martínez Santa and H.R. García Bernal, 2013. Proceso agroindustrial de la producción de panela. Tecnura, 17(35): 47-54.

Paramalingam, S., 2004. Modelling, optimisation and control of a falling-film evaporator. Ph.D. Thesis, Massey University, Palmerston North, New Zealand.

Perry, R. and D. Green, 2008. Perry's Chemical Engineers' Handbook. 8th Edn., McGraw-Hill, New York.

Poling, B.E., J.M. Prausnitz and J.P. O’Connell, 2001. The Properties of Gases and Liquids. 5th Edn., McGraw-Hill, New York.

Rahman, M.S., 2009. Food Properties Handbook.2nd Edn., CRC Press, Boca Raton.

Russell, N.T., H.H.C. Bakker and R.I. Chaplin, 2000. A comparison of dynamic models for an evaporation process. Chem. Eng. Res. Design., 78(8): 11201128.

Shah, D.J. and C.G. Bhagchandani, 2012. Design, Modelling and Simulation of Multiple Effect Evaporators. Int. J. Sci. Eng. Tech., 1(3): 1-5.

Smith, J.M., H.C. Van Ness, M.M. Abbott and E.A. Miguel, 2007. Introducción a la Termodinámica en Ingeniería Química. 7th Edn., McGraw-Hill, México D.F. 